\title{
VARIATIONS IN RAINFALL AND EXTREME EVENT INDICES IN THE WETTEST PART OF ETHIOPIA
}

\author{
Getenet Kebede ${ }^{1}$ and Woldeamlak Bewket ${ }^{2, *}$ \\ ${ }^{1}$ Department of Geography and Environmental Studies, Wollega University, PO Box 395 \\ Nekemte, Ethiopia. E-mail: abdi.waaq@gmail.com \\ 2 Department of Geography and Environmental Studies, Addis Ababa University, PO Box 50372 \\ Addis Ababa, Ethiopia. Email: wbewket@yahoo.com
}

\begin{abstract}
Changes in daily rainfall indices in the wettest (south-western) part of Ethiopia, commonly referred to as 'year-round' rainfall region were examined, by using records from nine stations over the period 1978-2007. Sixteen rainfall and dry spell related indices were defined and analyzed for trends; least squares regression was used to quantify trend and Kendall's tau test was used to test statistical significance of trend. A complex picture of rainfall variability emerges from the analysis. Only one station (Gore) shows a statistically significant decline. The same station (Gore) shows significant decreasing trends in very wet day (R95p) and extremely wet day (R99p) amounts, whereas another station (Jimma) shows significant increasing trends in these parameters (total rainfall, very wet day and extremely wet day amounts); the other stations show no significant trends in these indices. Two of the stations (Asendabo and Sokoru) show statistically significant increasing trends in the maximum number of consecutive dry days. The results generally support previous studies in Ethiopia that there are no consistent patterns or trends in daily rainfall characteristics or seasonal rainfalls with the additional finding that choice of study stations strongly influences results of trend analysis. This suggests that regional scale conclusions may not be provided by analysis of few selected stations, given the high level of spatial variability at subregional scales in Ethiopia.
\end{abstract}

Keywords: Climate change, daily rainfall, trend, Ethiopia

\section{INTRODUCTION}

Climate change is very likely to locally affect the intensity, frequency, duration and amounts of precipitation (New et al., 2000; Trenberth et al., 2003; IPCC, 2007), but the magnitude and direction of change will vary across regions and localities. The general consensus is, however, that the magnitude and frequency of extreme precipitation events will be increased as a result of increased global temperatures- which will lead to increased atmospheric moisture levels and thunderstorm activity (IPCC, 2007). Several empirical studies undertaken in different parts of the world have reported increase in large precipitation events during the period of instrumental records. For instance, increasing trends in the indices of extreme precipitation have been reported in the USA (Groisman et al., 2001; Kunkel, 2003), the UK for the winter season (Osborn et al., 2000), Italy (Brunetti et al., 2001a,b), India (Roy and Balling, 2004), South Africa (Mason et al., 1999), the southern African region

\footnotetext{
* Author to whom all correspondence should be addressed.
}

(Frich et al., 2002), and western part of New Zealand (Salinger and Griffiths, 2001).

Contrary to these and other studies, decreasing trends in large precipitation events have also been reported; for instance, in the UK for the summer season (Osborn et al., 2000), western part of Australia (Haylock and Nicholls, 2000), and northern and eastern parts of New Zealand (Salinger and Griffiths, 2001). Other studies reported absence of any trend in extreme precipitation events; for instance, in Canada (Zhang et al., 2001) and in the Yangtze river basin of China, where frequency of rainstorms (with $\geq 50 \mathrm{~mm}$ daily rainfall) has, however, shown a significant increase (Su et al., 2006). Gong et al. (2004) found a significant negative trend in the frequency of long wet spells, but a significant positive trend in the frequency of long dry spells in a semiarid region over northern China. New et al. (2006) reported absence of consistent and statistically significant trends in daily extreme precipitation indices across their study area that covers many countries in southern and western Africa.

In Ethiopia, most studies of long-term rainfall behaviour have considered only seasonal and annual amounts (Yilma Seleshi and Demarée, 
1995; Conway, 2000; Osman and Sauerborn, 2002; FEWS, 2003; Conway et al., 2004; Meze-Hausken, 2004; Cheung et al., 2008). Some of these studies reported that rainfall has recently exhibited a downward trend in parts of the country (Yilma Seleshi and Demarée, 1995; Osman and Sauerborn, 2002; FEWS, 2003), whereas others reported absence of any long-term trend in the areas and time periods they considered (Conway, 2000; Conway et al., 2004; Meze-Hausken, 2004). Others reported regionally differing patterns (Yilma Seleshi and Zanke, 2004; Cheung et al., 2008). For instance, Yilma Seleshi and Zanke (2004) found no trend in the annual and seasonal rainfall totals over the central, northern and north-western parts, but a declining trend in the eastern and south-western parts of the country during the period 1965-2002. Verdin et al. (2005) supported the findings of Yilma Seleshi and Zanke (2004) that annual rainfall has declined in the south-western part of the country, but argued that no trend existed in the June to September (i.e., Kiremt) rains for the entire nation since the 1960s. Cheung et al. (2008) also reported a significant decline in the Kiremt rainfall for watersheds in the south-western and central parts of Ethiopia, but no trend was found for watersheds in the other parts of the country over the period 1960-2002.

The main reason for the contrasting results of trend identification in seasonal and annual rainfall, particularly in the central and northern highlands of the country, is the use of different periods in the analyses; the 1980s were generally dry relative to preceding decades whilst rainfall recovered during the 1990s. Hence, trend analysis that ends during the late 1980s or early 1990s tends to show a declining trend, and when the period is extended this trend is reduced or even removed. Some of the studies (Yilma Seleshi and Demarée, 1995; Osman and Sauerborn, 2002) were also based on areal averages that may mask spatial variability and easily miss out localized trends given the diverse topography and microclimatic conditions of the country (Krauer, 1988). Moreover, intra-seasonal trends may exist in terms of daily rainfall characteristics while seasonal and annual amounts exhibit little or no change. Variations in total seasonal and annual rainfall can be caused by a change in the number of wet days, or the intensity of rainfall per wet day, or a combination of both. In order to provide a better understanding of rainfall behaviour, particularly as an indicator of climate change, daily precipitation series must be analyzed (Jones et al., 1999; Brunetti et al., 2001a).
The only available studies on characteristics of daily rainfall indices, which are commonly used as indices for climate change studies, in Ethiopia are by Yilma Seleshi and Zanke (2004), Yilma Seleshi and Camberlin (2006), and Woldeamlak Bewket and Conway (2007). Yilma Seleshi and Zanke (2004) studied changes in rainy days (with rainfall $>1.0 \mathrm{~mm}$ ) for 11 stations that were supposed to cover the entire country for the period 1965-2002 and found no trend over the central, northern and north-western parts, but a significant decline in the Kiremt rainy days in the eastern part of the country. By using data from the same stations, Yilma Seleshi and Camberlin (2006) examined changes in dry spell length and daily extreme rainfall events. They found decreasing trends in the kiremt and belg (MarchMay) extreme intensity and maximum consecutive 5-day rains over the eastern, southwestern and southern parts, but no trend in the remaining part of Ethiopia. The same study found no trend in length of maximum dry spells (consecutive days with $<1 \mathrm{~mm}$ rainfall) in both seasons. The study by Woldeamlak Bewket and Conway (2007) focused on the Amhara region and analyzed daily rainfall behaviour by using data from five key stations for the period 19612003. The results showed that there was no clear emergent patterns in mean wet day amount and probability of dry days (days with $<0.1 \mathrm{~mm}$ rainfall), and there was no trend in dry spell length in any of the stations. The study also reported that the extreme daily amounts considered $\left(5^{\text {th }}, 10^{\text {th }}, 90^{\text {th }}\right.$ and $95^{\text {th }}$ percentiles) also showed less coherent patterns of change across the region.

The aim of this study is to investigate the occurrence and magnitude of trends in extreme rainfall indices and dry and wet spells, which are commonly used as indices for climate change studies, in what is commonly known as the 'yearround' rainfall region of Ethiopia (south-western part of the country). This part of Ethiopia receives rainfall for an extended period of time in a year and hence is considered as an area having little or no drought-related problems. As a result no previous study has focused in this part of the country. The study by Cheung et al. (2008) covers the area with a good number of stations, but only seasonal and annual amounts are considered, which may have left out important details in daily rainfall behaviour. The present study is intended to contribute to filling in this gap, and has real benefits for designing effective strategies for reducing societal vulnerability to current climate variability and also to future changes in 
climate. It will also be an important contribution to the empirical literature on climate extremes in Africa, as New et al. (2006) note that there have been insufficient studies on precipitation or temperature related extremes in the continent.

\section{MATERIALS AND METHODS}

\section{The study area}

The study area constitutes part of the southwestern highlands of Ethiopia, which is characterized by high annual rainfall, large natural forest cover and dissected terrain. It is the wettest part of the country that receives rainfall continuously from March or April to October or November conveyed by wind systems coming from the Indian and Atlantic Oceans. According to NMSA (1996), the area receives rainfall for about nine to ten months per year. Extensive plateaus, valleys, gorges and low-lying plains characterize the physical landscape. Elevations range from over $2000 \mathrm{~m}$ to about $600 \mathrm{~m}$ in the lowlying parts. The area is drained by some of the major rivers of the country, such as the Omo, Baro and Didessa, and their numerous tributaries. These have created the dissected terrain. Nearly half of the country's remaining natural forests are found in this region. The forests are composed of different broadleaf species in a mixed stand and in layers with abundant shrubs at the bottom. Coffee is the most abundant shrub. For this reason the forests are often referred to as coffee forests. In addition to wild coffee, spices, honey and wildlife are the important non-timber products from the forest area. Presently, there is overexploitation of the forest resource for timber production. The farming system is a mixed crop-livestock system that is carried on a subsistence scale. Rain fed cultivation of cereals and traditional livestock husbandry are practiced. Perennial crops of coffee, enset (Enset ventricosum) and chat (Catha edulis) are also common in the area.

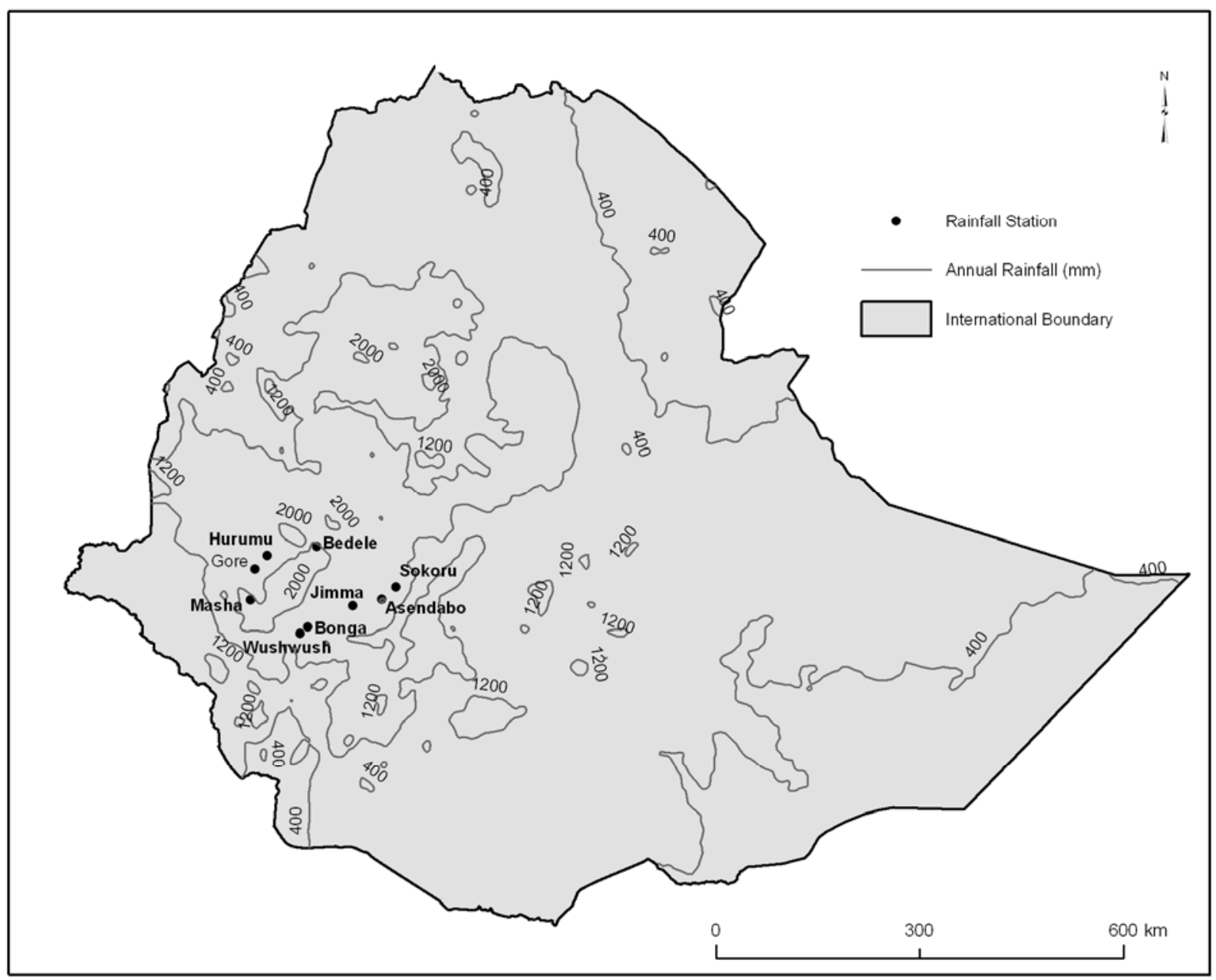

Fig. 1. Map of Ethiopia showing the study area and rainfall stations used. 


\section{Data and methods}

Daily rainfall records from nine stations that cover the study area were obtained from the National Meteorological Agency (NMA) for the period 1978/80-2007 (Table 1; Fig. 1). Station histories are not known, and no information is available on whether or not any of the stations has experienced change in location, environmental conditions and/or observation practice. Such changes obviously have important implications on homogeneity of records and thereby on detecting changes in the frequency of extreme events on daily time scales. The stations were selected based primarily on the criteria of having continuous records with little or no missing values and geographic distribution such that adequate coverage is ensured for the area studied. All the records were screened for discontinuities, outliers and obvious errors by using graphical methods and cross-checked with records from neighbouring stations and removed where judged erroneous. As the period covered is recent, there were only very few missing records and these were filled in by using mean values for that year. The Standard Normal Homogeneity Test (SNHT) was used to determine homogeneity of the records following the approach in Wijngaard et al. (2003) and it was found that all the records are homogenous. Wijngaard et al. (2003) used this method, along with three others, to evaluate homogeneity of $20^{\text {th }}$ century European daily temperature and precipitation series.

From the daily data, 16 rainfall and dry spellrelated indices were defined and calculated for each of the nine stations. Table 2 presents definitions for the indices used. In this study a day with a rainfall total of $1 \mathrm{~mm}$ or more is defined as wet day, and a dry day is a day with a rainfall total of less than $1 \mathrm{~mm}$. Most of the indices relate to extreme rainfall, whereas the total annual wet day rainfall (RFTOT) and the average wet day intensity are more indicative of the changes to the entire rainfall distribution. Least squares regression was used to quantify trend and the Kendall's tau test was used to test statistical significance of trend for the annual series of each of the various indices. The statistical analyses were undertaken using Instat, Excel and SPSS software. In addition, variability of time series of the indices was examined by calculating the coefficient of variability for each. The Instat package was developed by the statistical services centre of the University of Reading for analysis of rainfall data.

Table 1. Selected rainfall stations used for the study.

\begin{tabular}{lllll}
\hline Stations & $\begin{array}{c}\text { Lat. } \\
\text { (degree) }\end{array}$ & $\begin{array}{c}\text { Long. } \\
\text { (degree) }\end{array}$ & $\begin{array}{l}\text { Alt. } \\
\text { (masl) }\end{array}$ & $\begin{array}{l}\text { Years of } \\
\text { observation }\end{array}$ \\
\hline Asendabo & 7.76 & 37.23 & 2400 & $1978-2007$ \\
Bedele & 8.45 & 36.33 & 2030 & $1978-2007$ \\
Bonga & 7.22 & 36.23 & 1650 & $1980-2007$ \\
Gore & 8.15 & 35.53 & 2002 & $1978-2007$ \\
Hurumu & 8.36 & 35.78 & 1950 & $1980-2007$ \\
Jimma & 7.66 & 36.83 & 1725 & $1978-2007$ \\
Masha & 7.60 & 35.50 & 2310 & $1980-2007$ \\
Sokoru & 7.92 & 37.40 & 2100 & $1980-2007$ \\
Wushwush & 7.32 & 36.13 & 1950 & $1980-2007$ \\
\hline
\end{tabular}

Table 2. Rainfall indices and their definitions used in the study.

\begin{tabular}{|c|c|c|c|}
\hline Index & Descriptive Name & Definition & Units \\
\hline Rdays & Rainy days & Number of rainy days & days \\
\hline RFTOT & Wet day precipitation & Annual total precipitation from wet days & $\mathrm{mm}$ \\
\hline RX 5 days & Maximum 5 day precipitation & Annual maximum consecutive 5 days precipitation & $\mathrm{mm}$ \\
\hline SDII & Simple Daily Intensity Index & Average precipitation on wet days in the year & $\mathrm{mm} / \mathrm{d}$ \\
\hline $\mathrm{R} 20 \mathrm{~mm}$ & Heavy precipitation days & Annual count of days when $R R>=20 \mathrm{~mm}$ & days \\
\hline CDD & Consecutive Dry Days & Maximum number of consecutive dry days & days \\
\hline CWD & Consecutive Wet Days & Maximum number of consecutive wet days & days \\
\hline R95p & Very wet day precipitation & $\begin{array}{l}\text { Annual total precipitation when } R R>95^{\text {th }} \text { percentile of } 1978-2007 \\
\text { daily rain fall }\end{array}$ & $\mathrm{Mm}$ \\
\hline $\mathrm{R} 99 \mathrm{p}$ & $\begin{array}{l}\text { Extremely wet day } \\
\text { precipitation }\end{array}$ & $\begin{array}{l}\text { Annual total precipitation when } R R>99^{\text {th }} \text { percentile of } 1978-2007 \\
\text { daily rain fall }\end{array}$ & $\mathrm{Mm}$ \\
\hline SDS & Short Dry Spells & Frequency of short dry spells (1-4) days & days \\
\hline LDS & Long Dry Spells & Frequency of long dry spells at least 10 days & days \\
\hline LWS & Long Wet Spells & Frequency of long wet spells at least 10 days & days \\
\hline $\mathrm{MnD}$ & Mean dry spell & Mean dry spell length & days \\
\hline $\mathrm{MnW}$ & Mean wet spell & Mean wet spell length & days \\
\hline
\end{tabular}




\section{RESULTS}

\section{Variations in annual precipitation and rainy days}

The mean annual total rainfall in the area varies from about $1165 \mathrm{~mm}$ (at Asendabo) to nearly $2270 \mathrm{~mm}$ (at Masha) (Table 3). Three stations (Asendabo, Jimma and Sokoru) out of the nine receive annual rainfall of $<1500 \mathrm{~mm}$, while at four of the stations annual rainfalls are over 1850 $\mathrm{mm}$. Inter-annual variability of rainfall is relatively low except at Hurumu, as shown by the coefficients of variations. The mean annual areal rainfall is $1698.3 \mathrm{~mm}$ with a standard deviation of about 144 . Figure 2 shows standardized inter-annual variability of the areal annual rainfall. It is shown that 1997 and 2002 were the wettest and the driest years on record, respectively. The other important wet years were 1988 and 1997. The years with significant negative anomalies in the region (1979, 1994, 1995 and 2002) were drought years in many parts of Ethiopia.



Fig. 2. Standardized inter-annual (SIV) variability of areal rainfall.
Figure 3 shows inter-annual rainfall variability at each of the nine stations. At station level, the proportion of negative anomalies was lowest at Bonga (36\% of observations) and highest at Jimma (57\% of observations). Most of the negative anomalies have occurred during 20022007, suggesting some declines of rainfall in recent years. It also appears that there has been a decrease in the duration of the rainy season. According to NMSA (1996), the area experiences nine to ten months of rainfall, but this study has found that the maximum duration of the rainy season is about seven months. Over the past three decades, six out of the nine stations have shown negative trends in annual rainfall; however, only two stations (Gore and Jimma) have experienced statistically significant changes. Rainfall has decreased by $84.4 \mathrm{~mm}$ per decade at Gore, but increased by $61.5 \mathrm{~mm}$ at Jimma.

The average number of rainy days per year ranges from about 122 at Asendabo to 213 at Masha. This corresponds with annual total amount of rainfall, which is highest at Masha and lowest at Asendabo. Statistically significant increasing trend at Asendabo (5.3 days per decade) and decreasing trend at Bonga (9.4 days per decade) were observed in the number of rainy days. The average wet day rainfall varies between $9.5 \mathrm{~mm}$ at Bonga and $18.6 \mathrm{~mm}$ at Gore. No statistically significant change has been observed in the mean wet day amount except at Sokoru.

Table 3. Annual rainfall (RFTOT) and rainy days (Rdays) at the nine stations. (Figures in brackets are coefficients of variations (\%); LT= linear trend per decade).

\begin{tabular}{lrrrrrr}
\hline Stations & RFTOT $(\mathrm{mm})$ & LT & Rdays & LT & $\begin{array}{r}\text { SDII } \\
(\mathrm{mm} / \text { day })\end{array}$ & LT \\
\hline Asendabo & $1165.7(11.1)$ & 57.4 & $121.9(8.6)$ & $5.3^{*}$ & $9.6(8.3)$ & 0.02 \\
Bedele & $1852.0(14.2)$ & 32.3 & $152.6(9.7)$ & 2.93 & $12.2(13.1)$ & -0.08 \\
Bonga & $1678.6(12.0)$ & -36.7 & $177.9(11.8)$ & $-9.4^{*}$ & $9.5(15.8)$ & 0.21 \\
Gore & $1856.8(13.6)$ & $-84.4^{* *}$ & $174.5(6.1)$ & -0.51 & $18.6(15.6)$ & -1.19 \\
Hurumu & $1905.3(26.0)$ & -73.5 & $155.8(8.1)$ & 0.28 & $12.2(25.4)$ & -0.46 \\
Jimma & $1491.3(13.7)$ & $61.5^{*}$ & $152.3(7.4)$ & -0.77 & $16.9(18.9)$ & 0.15 \\
Masha & $2269.7(15.3)$ & -131.7 & $212.7(9.0)$ & -1.99 & $10.7(14.9)$ & -0.49 \\
Sokoru & $1375.8(12.2)$ & -48.7 & $142.4(14.0)$ & 3.56 & $9.8(18.3)$ & $-0.9^{*}$ \\
Wushwush & $1769.0(12.9)$ & -57.4 & $176.4(8.9)$ & -5.22 & $10(11.0)$ & 0.06 \\
Areal mean & $1698.3(8.5)$ & 21.5 & $162.0(6.6)$ & -0.21 & $12.4(9.7)$ & $-0.44^{*}$ \\
\hline
\end{tabular}

**Significant at the 0.01 level; *Significant at the 0.05 level. 

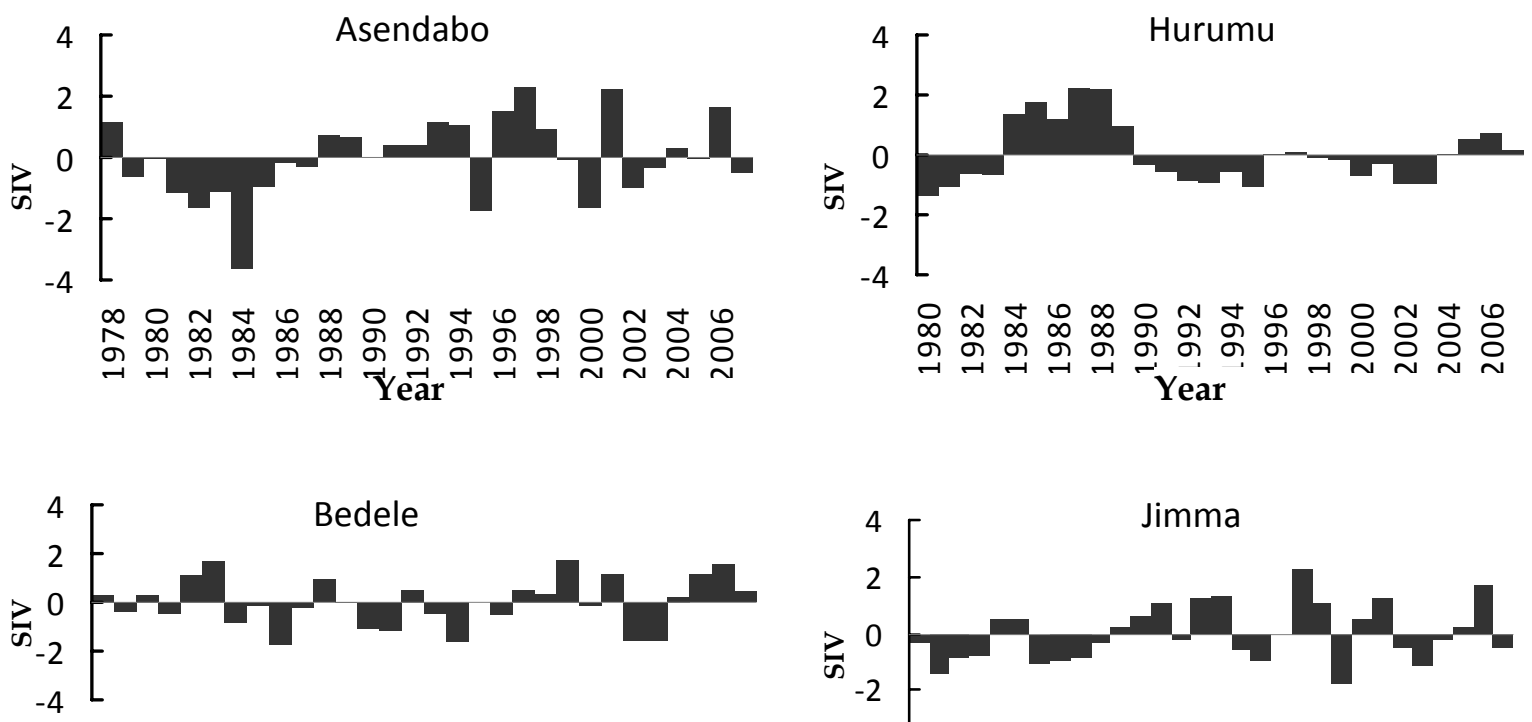

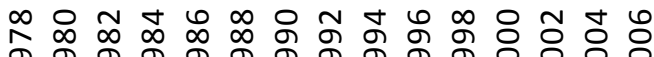

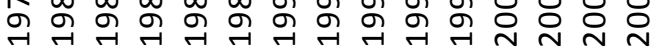

Year

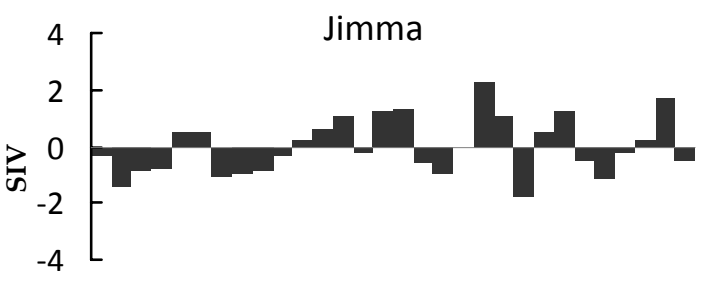

$\infty \circ \sim \forall \infty$

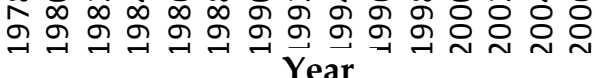
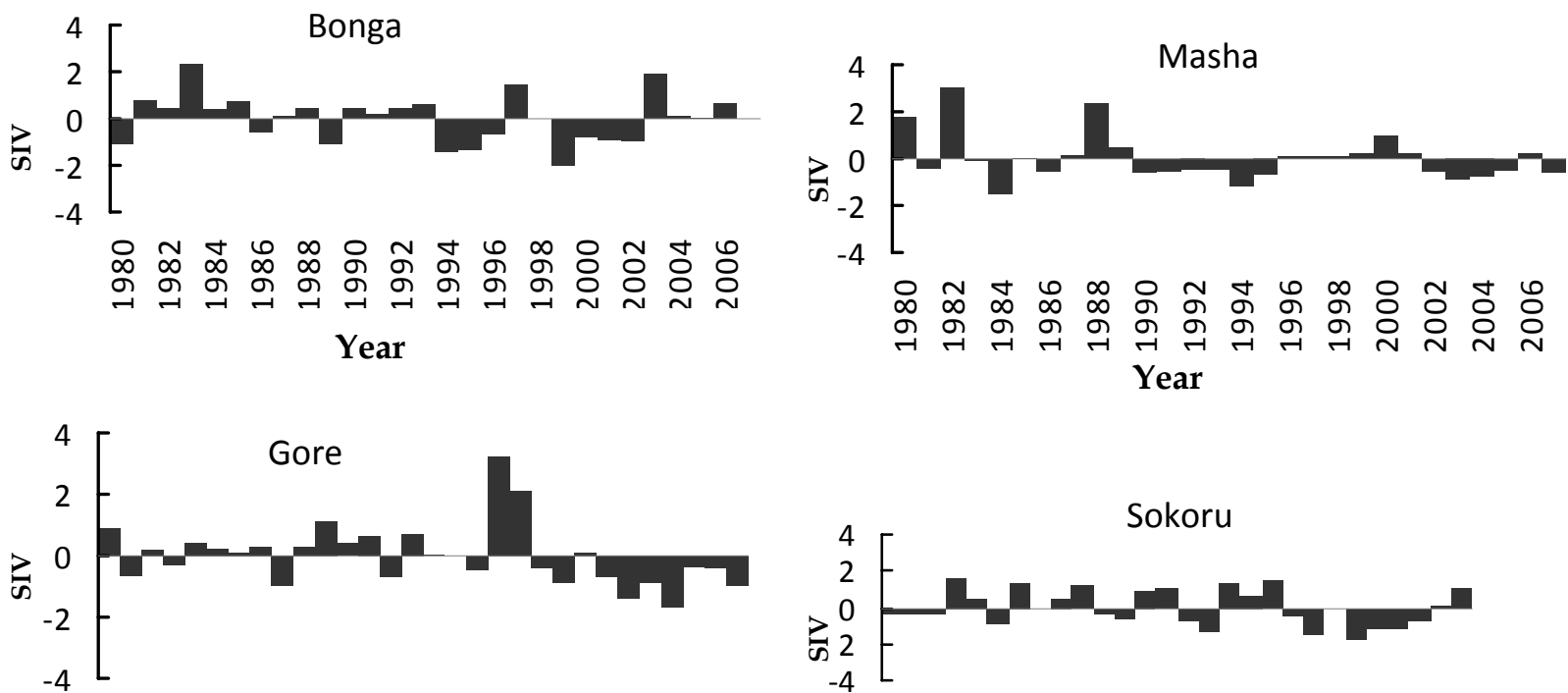

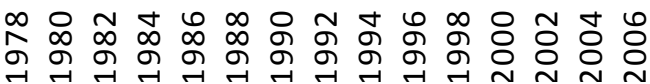

Year

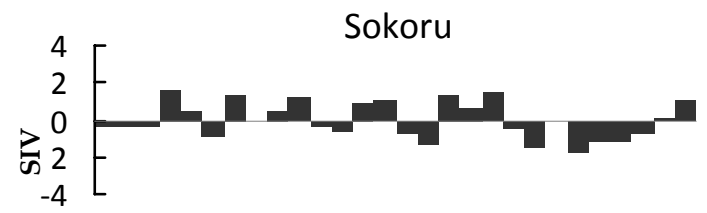

잉 Year

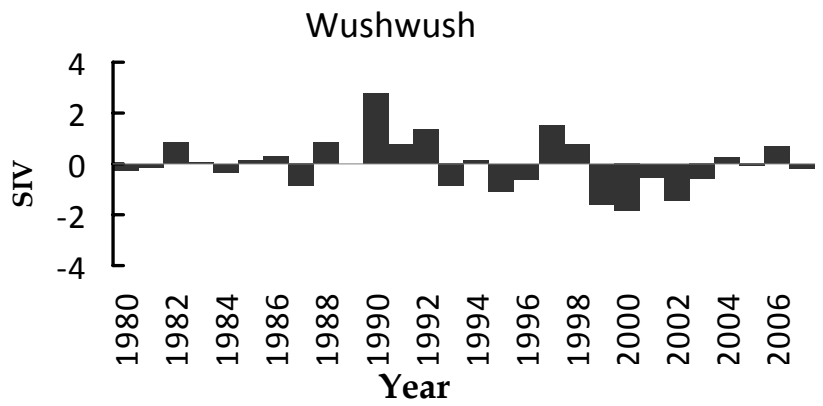

Fig. 3. Standardized inter-annual variability (SIV) of rainfall at the nine stations. 


\section{Variations in extreme rainfall events}

Table 4 presents indices of extreme rainfall events at the nine stations. The mean maximum one day precipitation (Rx1day) was over $50 \mathrm{~mm}$ in all of the stations except at Bonga where it is about $45 \mathrm{~mm}$; the inter-station differences are not large. On average, wet days with at least $20 \mathrm{~mm}$ of rainfall vary between about 8 days per year at Bedele and about 31 days per year at Masha. Expectedly, mean annual very wet day precipitation (R95p) and extremely wet day precipitation (R99p) exhibit similar patterns with that of mean annual total rainfall; i.e. highest at Masha and lowest at Asendabo. Similarly, mean annual maximum consecutive 5-day rainfall ( $\mathrm{Rx} 5$ days) is highest at Masha (119 $\mathrm{mm})$ and lowest at Asendabo (90 mm).

Only few of the indices at some of the stations have shown statistically significant trends during the period studied. At Sokoru, one day maximum (Rx1day) and consecutive 5-day maximum (Rx5days) amounts have decreased at the rate of $6.2 \mathrm{~mm}$ and $12.8 \mathrm{~mm}$ per decade, respectively, both significant at the 0.05 level. At Bedele, one day maximum amount (Rx1day) has increased at the rate of $5.8 \mathrm{~mm}$ per decade. The number of days with heavy rainfall (R20mm) shows declining trends in four of the nine stations, but only statistically significant at Gore (decreased by 3.6 days per decade). At the other stations, the trends in this index are positive, but not significant statistically except at Jimma where it has increased at the rate of 1.9 days per decade. The declining trends at Gore for very wet day (R95p) and extremely wet day (R99p) amounts are statistically significant at $<0.01$ level. At most of the stations, these indices show negative but statistically non-significant trends. Averaged for the entire area, or the nine stations, none of the indices show statistically significant change over the period of observation.

\section{Variations in wet and dry spells}

The mean maximum number of consecutive wet days (CWD) in the area range from 9 days at Asendabo to 24 days at Masha, while the average duration of wet spells is 0.9 and 3.1 days at Asendabo and Masha, respectively (Table 4a). No statistically significant trend is observed in the maximum number of consecutive wet days although negative signs of change are observed at eight of the nine stations. Similarly, the only statistically significant change in mean wet spell length is at Wushwush where it has decreased by 0.5 days per decade. Significant decreasing trends are also shown by the annual frequencies of short wet spells (1-4 days) at Gore and long wet spells ( $>=10$ days) at Bonga and Wushwush. The frequency of short wet spell length has shown significant positive changes at Masha and Wushwush.

The maximum number of consecutive dry days (CDD) is shortest at Masha ( 17 days) and longest at Asendabo ( $\sim 46$ days), and the mean dry spell length is 1.6 days at Masha and 4.9 days each at Asendabo and Bedele (Table 4b). Six of the stations out of nine have experienced increasing trends in the maximum number of consecutive dry days, two of which (Asendabo and Sokoru) are statistically significant. The frequency of short dry spells has increased at Masha but decreased at Gore, while the frequency of long dry spells increased at Jimma but decreased at Sokoru.

Table 4. Indices of extreme rainfall events at the nine stations.

\begin{tabular}{lrrrrrrrrrr}
\hline Stations & RX1day & LT & RX5days & LT & R20mm & LT & R95p & LT & R99p & LT \\
\hline Asendabo & 55.4 & 0.59 & 90.4 & -1.99 & 15.2 & 0.20 & 1107.4 & 54.57 & 1154.1 & 56.87 \\
Bedele & 56.8 & $5.8^{*}$ & 117.3 & 4.95 & 8.0 & 0.31 & 1759.4 & 30.65 & 1833.5 & 31.94 \\
Bonga & 45.3 & -0.64 & 94.8 & 2.89 & 18.2 & 0.12 & 1594.6 & -34.48 & 1661.8 & -36.34 \\
Gore & 58.7 & -0.55 & 101.7 & 2.00 & 26.6 & $-3.6^{*}$ & 1764.0 & $-80.1^{* *}$ & 1838.2 & $-83.5^{* *}$ \\
Hurumu & 62.8 & -4.01 & 118.0 & -4.72 & 30.0 & 0.76 & 1810.0 & -69.78 & 1886.2 & -72.71 \\
Jimma & 51.5 & -0.94 & 91.5 & 4.28 & 18.8 & $1.9^{*}$ & 1416.8 & 58.44 & 1476.4 & 60.90 \\
Masha & 57.7 & 0.57 & 119.4 & -13.02 & 31.4 & -2.62 & 2156.2 & -125.20 & 2247.0 & -130.40 \\
Sokoru & 50.0 & $-6.2^{*}$ & 94.1 & $-12.8^{*}$ & 17.6 & -1.81 & 1307.0 & -46.23 & 1362.0 & -48.18 \\
Wushwush & 52.4 & 1.12 & 98.6 & -2.44 & 23.5 & -0.05 & 1680.6 & -54.60 & 1751.3 & -56.87 \\
Areal mean & 54.4 & 0.83 & 102.4 & 1.02 & 20.8 & 0.39 & 1570.5 & 32.49 & 1681.3 & 21.33 \\
\hline
\end{tabular}


Table 4a. Variations in wet spells in the selected stations.

\begin{tabular}{lrrrrrrrr}
\hline Stations & CWD & LT & SWS & LT & LWS & LT & MnW & LT \\
\hline Asendabo & 9.1 & -0.14 & 51.8 & 1.75 & 0.5 & -0.09 & 0.9 & 0.04 \\
Bedele & 16.1 & -0.55 & 39.9 & -2.54 & 2.4 & 0.28 & 1.6 & -0.04 \\
Bonga & 16.6 & -0.56 & 47.4 & 2.70 & 2.8 & $-1.1^{*}$ & 1.9 & -0.23 \\
Gore & 17.8 & -0.61 & 40.6 & $-3.0^{*}$ & 3.3 & 0.18 & 2.0 & 0.00 \\
Hurumu & 18.9 & -0.19 & 37.5 & -1.46 & 3.1 & -0.26 & 1.8 & -0.03 \\
Jimma & 11.3 & 0.08 & 52.6 & 0.36 & 1.1 & -0.01 & 1.3 & -0.01 \\
Masha & 24.3 & -3.90 & 41.9 & $3.04^{*}$ & 4.5 & -0.17 & 3.1 & -0.49 \\
Sokoru & 11.1 & -0.31 & 43.4 & -0.27 & 1.6 & -0.27 & 1.1 & 0.01 \\
Wushwush & 14.1 & -1.58 & 49.1 & $4.93^{*}$ & 2.4 & $-0.7^{*}$ & 1.9 & $-0.5^{* *}$ \\
Areal mean & 15.0 & -0.22 & 45.0 & 0.99 & 2.4 & -0.08 & 18.2 & -0.04 \\
\hline
\end{tabular}

${ }^{* *}$ Significant at the 0.01 level; ${ }^{*}$ Significant at the 0.05 level.

Table $4 \mathrm{~b}$. Variations in dry spells in the selected stations.

\begin{tabular}{lrrrrrrrr}
\hline Stations & CDD & LT & SDS & LT & LDS & LT & MnD & LT \\
\hline Asendabo & 46.3 & $6.91^{*}$ & 44.7 & 2.10 & 6.1 & -0.26 & 4.9 & 0.39 \\
Bedele & 38.4 & -0.96 & 40.4 & -0.78 & 6.0 & 0.29 & 4.9 & 0.00 \\
Bonga & 25.0 & 3.83 & 49.3 & 1.75 & 3.5 & -0.12 & 2.6 & 0.33 \\
Gore & 29.3 & 1.74 & 43.7 & $-2.51^{*}$ & 5.1 & 0.07 & 3.4 & 0.25 \\
Hurumu & 36.8 & 3.32 & 37.9 & -0.15 & 6.1 & 0.03 & 4.8 & 0.55 \\
Jimma & 31.4 & 3.44 & 50.0 & 0.42 & 4.5 & $0.02^{*}$ & 3.1 & 0.20 \\
Masha & 16.6 & -0.75 & 48.4 & $3.48^{* *}$ & 2.4 & -0.41 & 1.6 & -0.04 \\
Sokoru & 42.4 & $8.79^{*}$ & 43.2 & 1.66 & 5.3 & $-1.13^{* *}$ & 5.8 & 0.99 \\
Wushwush & 25.0 & -0.02 & 51.3 & 3.78 & 3.5 & -0.03 & 2.6 & -0.10 \\
Areal mean & 32.5 & 2.93 & 45.4 & $1.65^{*}$ & 4.7 & -0.09 & 18.8 & $0.27^{*}$ \\
\hline
\end{tabular}

** Significant at the 0.01 level; * Significant at the 0.05 level.

\section{DISCUSSIN AND CONCLUSIONS}

This paper presents analyses of trends in extreme rainfall indices and dry and wet spells, which are commonly used as indices in climate change studies, in the south-western part of Ethiopia where no previous study has been undertaken at the same level of spatial and temporal resolution. The study used daily rainfall records from nine stations for the period 1978-2007. The main findings of this study are the following.

i. Annual rainfall in the area varies from about $1165 \mathrm{~mm}$ (at Asendabo) to nearly $2270 \mathrm{~mm}$ (at Masha); with an areal average of about 1698 mm. In the region as a whole 1988, 1997 and 2006 stand out as very wet years, while 1979, 1994, 1995 and 2002 were very dry years; 1997 and 2002 were the wettest and the driest years on record, respectively. Most of the negative anomalies at the individual stations have occurred during 2002-2007, suggesting some declines of rainfall in recent years. Six out of the nine stations have shown negative trends in annual rainfall; however, only one station (Gore) has experienced a statistically significant decline.

ii. Annual rainy days vary from 121 to 212 at Asendabo and Masha, respectively. These are 
equivalent to four to seven months. Comparing this with previous reports (NMSA, 1996), it appears that the area has experienced reduction of rainy months. Yilma Seleshi and Zanke (2004) and Verdin et al. (2005) also found a declining trend in annual and seasonal rainfall totals in the south-western part of the country. For the period 1978-2007, however, the only statistically significant changes in number of rainy days are the increasing trend at Asendabo and the decreasing trend at Bonga. The average wet day rainfall varies between $9.5 \mathrm{~mm}$ and $18.6 \mathrm{~mm}$. No statistically significant change has been observed in the mean wet day amount except at one station (at Sokoru).

iii. Trend analysis of daily extreme indices shows no clear emergent patterns. Gore shows significant decreasing trends in total rainfall amount, very wet day (R95p) and extremely wet day (R99p) amounts, whereas Jimma shows significant increasing trends in these parameters (total rainfall, very wet day and extremely wet day amounts); the other stations show no significant trends in these indices. Sokoru shows significant deceasing trends for one day maximum (Rx1day), consecutive 5-day maximum (Rx5days) amounts and average daily intensity. It is only at Bedele that maximum one day rainfall amount has significantly increased. The other stations show no significant trend in these indices.

iv. From analysis of wet and dry spells, the maximum number of consecutive wet days shows negative but not statistically significant changes at eight of the nine stations. However, Wushwush shows significant deceasing trend in mean wet spell length. Six of the stations out of nine have experienced increasing trends in the maximum number of consecutive dry days, two of which (Asendabo and Sokoru) are statistically significant.

A major impact of climate change is related to frequency of occurrence of hydrological extremes; i.e. floods and droughts (Easterling et al., 2000). The magnitude and frequency of extreme rainfall events is very likely to increase as a result of climate change (New et al., 2000; IPCC, 2007), with implications for increased frequency and severity of flood disasters.
Similarly, droughts are predicted to become more severe where they occur, and rainfall variability is expected to increase in the already dry environments (IPCC, 2007). Variations in total rainfall can be caused by a change in the frequency of rainy days, or the intensity of rainfall per rainy day, or a combination of both (New et al., 2000; Trenberth et al., 2003). In other words, changes in rainfall characteristics may occur with or without changes in total seasonal or annual amounts. All these changes have important implications for adaptation planning to changing climatic conditions and thus warrant a detailed investigation and understanding at local scales.

This study assesses existence and magnitude of trends in extreme rainfall indices and dry and wet spells, which are commonly used as indices for climate change studies, in the wettest part of Ethiopia. No previous study has examined daily rainfall behaviour in this part of the country at the level of detail presented here. This is partly because the area receives rainfall for an extended period of time in a year and hence considered as an area having little or no drought-related problems. The previous studies, cited elsewhere above, were focused on drought-prone areas, as drought has historically been the major climaterelated hazard and immediate cause of food shortages and famines in the country (Wood, 1977; Pankhurst and Johnson, 1988). This study therefore fills in an important knowledge gap in terms of spatial coverage as well, while contributing to the little available literature on characteristics of daily rainfall indices in the country.

The findings of this study generally support those of the previous studies undertaken in different parts of Ethiopia that there are no consistent patterns or trends in daily rainfall characteristics or seasonal rainfalls (e.g., Yilma Seleshi and Zanke, 2004; Verdin et al., 2005; Yilma Seleshi and Camberlin, 2006; Woldeamlak Bewket and Conway, 2007; Cheung et al., 2008). Also, it is noted in this study that choice of study stations and study period strongly influence results of trend analysis. This suggests that regional scale conclusions may not be provided by analysis of few selected stations given the high level of spatial variability at sub-regional scales. This study also shows the complexity of 
spatial variability of rainfall in the country, with implications for station density to monitor climate change and design appropriate community-based adaptation measures.

The findings of this study have important practical implications for local scale agricultural planning, natural resources management and planning for adaptation to climate change, which ought to take into account potential impacts of rainfall variability in the area. Rainfall variability has historically been a heavy burden on the economy, society and environment of Ethiopia (Wood, 1977; RRC, 1985; Pankhurst and Johnson, 1988; Von Braun, 1991; World Bank, 2006; NMA, 2007). For instance, World Bank (2006) states that "hydrological variability (including droughts and floods) costs the Ethiopian economy $38 \%$ of its potential growth rate". In spite of such a high degree of vulnerability, studies related to rainfall characteristics and hydrological extremes, impacts of such extremes on local communities and adaptation options are very few in the country. Hence, more work needs to be done to better understand small scale changes in daily rainfall behaviour as any change in rainfall distribution and negative trends associated with climate change will have serious implications on national food security and economic development. Combining rainfall data analysis with analysis of stream discharge data will provide additional information on impacts of climate change.

\section{ACKNOWLEDGEMENTS}

The authors would like to thank the National Meteorological Agency (NMA) for kindly providing the daily rainfall data used for the study. We would also like to express our gratitude to the two anonymous reviewers for their valuable comments and suggestions.

\section{REFERENCES}

1. Brunetti, M., Maugeri, M. and Nanni, T. (2001b). Changes in total precipitation, rainy days and extreme events in north-eastern Italy. International Journal of Climatology 21:861-871.

2. Brunetti, M., Colacino, M., Maugeri, M. and Nanni, T. (2001a). Trends in daily intensity of precipitation in Italy from 1951 to 1996. International Journal of Climatology 21:299-316.

3. Cheung, W.H, Gabriel Senay and Singh, A. (2008). Trends and spatial distribution of annual and seasonal rainfall in Ethiopia. International Journal of Climatology 28:1723-1734.

4. Conway, D. (2000). The climate and hydrology of the upper Blue Nile River. The Geographical Journal 166:49-62.

5. Conway, D., Mould, C. and Woldeamlak Bewket (2004). Over one century of rain fall and temperature observations in Addis Ababa, Ethiopia. International Journal of Climatology 24:77-91.

6. Easterling, D., Evans, J.L., Groisman, P.Y., Karl, T.R., Kunkel, K.E. and Ambenje, P. (2000). Observed variability and trends in extreme climate events: a brief review. Bulletin of the American Meteorological Society 81:417-425.

7. Easterling, D., Meehl, G., Parmesan, C., Changnon, S., Karl, T. and Mearns, L. (2000). Climate extremes: observations, modeling, and impacts. Science 289:2068-2074.

8. FEWS (Famine Early Warning System) (2003). FEWS Ethiopia food security update, 14 August 2003. http//www.fews.net (accessed on September 2004).

9. Frich, P., Alexander, L.V., Della-Marta, P., Gleason, B., Haylock, M., Klein, A.M.G. and Peterson, T. (2002). Observed coherent changes in climatic extremes during the second half of the twentieth century. Climate Research 19:193-212.

10. Gong, D., Shi, P. and Wang, J. (2004). Daily precipitation changes in the semi-arid region over northern China. Journal of Arid Environments 59:771-784.

11. Groisman, P.Y., Knight, R.W. and Karl, T.R. (2001). Heavy precipitation and high stream flow in the contiguous United States: trends in the twentieth century. Bulletin of the American Meteorological Society 82:219-246.

12. Haylock, M. and Nichollas, N. (2000).Trends in extreme rainfall indices for unupdated high quality data set for Australia, 1910-1998. International Journal of Climatology 20:15331541.

13. IPCC (Intergovernmental Panel on Climate Change). (2007). Climate Change 2007: The Physical Science Basis. Cambridge University Press.

14. Jones, P.D., Horton, E.B., Folland, C.K., Hulme, M., Parker, D.E. and Basnett, T.A. (1999). The 
use of indices to identify changes in climate extremes. Climatic Change 42:131-149.

15. Krauer, J. (1988). Rainfall, erosivity and isoerodent map of Ethiopia. Research Report no. 15, SCRP, Ministry of Agriculture, Addis Ababa.

16. Kunkel, K.E. (2003). North American trends in extreme precipitation. Natural Hazards 29:291305.

17. Mason, S.J., Waylen, P.R., Mimmack, G.M., Rajaratnam, B. and Harrison, J.M. (1999). Changes in extreme rainfall events in South Africa. Climatic Change 41:249-257.

18. Meze-Hausken, E. (2004). Contrasting climate variability and meteorological drought with perceived drought and climate change in northern Ethiopia. Climate Research 27:19-31.

19. New, M., Hewiston, B., Stephenson, D.B., Tsiga, A., Kruger, A., Manhique, A., Gomez, B., Coelho, C.A.S, Masisi, D.N., Kululanga, E., Mbamalala, E., Adersina, F., Saleh, H., Kanyanga, J., Adosi, J., Bulane, L., Fortunata, L., Mdoka, M.L. and Lojoie, R. (2006). Evidence of trends in daily climate extremes over Southern and West Africa. Journal of Geophysical Research 111, D14102, Doi: 10.1029/2005JD006289.

20. New, M., Todd, M., Hulme, M. and Jones, P. (2000). Precipitation measurements and trends in the twentieth century. International Journal of Climatology 21:1899-1922.

21. NMA (National Meteorological Agency of Ethiopia) (2007). Climate change national adaptation program of action (NAPA) of Ethiopia. Ministry of Water Resources, Addis Ababa.

22. NMSA (National Meteorological Services Agency of Ethiopia) (1996). Climatic and agroclimatic resources of Ethiopia. Meteorological Research Report Series, Vol. I. NMSA, Addis Ababa.

23. Osborn, T.J., Hulme, M., Jones, P.D. and Basnett, T.A. (2000). Observed trends in the daily intensity of United Kingdom precipitation. International Journal of Climatology 20:347-364.

24. Osman, M. and Sauerborn, P. (2002). A preliminary assessment of characteristics and long- term variability of rain fall in EthiopiaBasis for sustainable land use and resource management. Conference on International Agricultural Research for Development. Deutscher Tropentang, Witzenhausen, 9-11 October, 2002.

25. Pankhurst, R. and Johnson, D.H. (1988). The great drought and famine of 1888-92 in northeast
Africa. In: The Ecology of Survival: Case Studies from Northeast African History, pp. 47-72, (Johnson, D.H. and Anderson, D.M., eds). Lester Crook Academic Publishing, London.

26. Roy, S.S. and Balling, R.C. (2004). Trends in extreme daily precipitation indices in India. International Journal of Climatology 24:457-466.

27. RRC (1985). Combating the Effects of Cyclical Drought in Ethiopia. Relief and Rehabilitation Commission (RRC), Addis Ababa.

28. Salinger, M.J. and Griffiths, G.M. (2001). Trends in New Zealand daily temperature and rainfall extremes. International Journal of Climatology 21:1437-1452.

29. Su, B.D., Jiang, T. and Jin, W.B. (2006). Recent trends in observed temperature and precipitation extremes in the Yangtze river basin, China. Theoretical and Applied Climatology 83:139-151.

30. Trenberth, K.E., Dai, A., Rasmussen, R.M. and Parsons, D.B. (2003). The changing character of precipitation. Bulletin of the American Meteorological Society 84:1205-1217.

31. Verdin, J., Funk, C., Gabriel Senay and Choularton, R. (2005). Climate science and famine early warning. Philosophical Transactions of the Royal Society of London, Series B-Biological Sciences 360:2155-2168.

32. Von Branu, J. (1991). A policy agenda for famine prevention in Africa. Food Policy Statement 13, IFPRI, Washington DC.

33. Wijngaard, J.B., Klein, A.M.G. and Konnen, G.P. (2003). Homogeneity of 20 th century European daily temperature and precipitation series. International Journal of Climatology 23:679-692.

34. Woldeamlak Bewket and Conway, D. (2007). A note on the temporal and spatial variability of rainfall in the drought prone Amhara region of Ethiopia. International Journal of Climatology 27:1467-1477.

35. Wood, A. (1977). A preliminary chronology of Ethiopian droughts. In: Drought in Africa, Vol. 2, pp. 68-73, (Dalby, D., Church, R.J.H., Bezzaz, F., eds). International African Institute, London.

36. World Bank (2006). Ethiopia: Managing Water Resources to Maximize Sustainable Growth: A World Bank Water Resources Assistance Strategy for Ethiopia. World Bank, Washington DC.

37. Yilma Seleshi and Camberlin, P. (2006). Recent changes in dry spell and extreme rain fall 
events in Ethiopia. Theoretical and Applied Climatology 83:181-192.

38. Yilma Seleshi and Demarée, G.R. (1995). Rainfall variability in the Ethiopian and Eritrean highlands and its links with the southern oscillation index. Journal of Biogeography 22:945-952.
39. Yilma Seleshi and Zanke, U. (2004). Recent changes in rainfall and rainy days in Ethiopia. International Journal of Climatology 24:973-983.

40. Zhang, X., Hogg, W.D. and Mekis, F. (2001). Spatial and temporal characteristics of heavy precipitation events over Canada. Journal of Climate 14:1923-1936. 